\title{
Pusat Pertumbuhan Ekonomi Dan Kontribusinya Pada Pengembangan Daerah Pendukung Di Lombok Timur NTB.
}

\author{
Hailuddin, Luluk Fadliyanti, Bq. Saripta Wijimulawiani. \\ Universitas Mataram
}

\begin{tabular}{l|l}
\hline A R T ICLE IN F O & Received : 22 Juni 2018; Accepted: 29 Juli 2018; Published: September 2018 \\
\hline $\begin{array}{l}\text { Keywords: } \\
\text { Hinterland, the spread } \\
\text { effect, Central Regional } \\
\text { Activities. }\end{array}$ & $\begin{array}{l}\text { ABSTRACT : Each region has the authority to determine its regional activity center to } \\
\text { accelerate its development. After determining and executing of the regional activity } \\
\text { center, it is then important to assess whether the plan is according to expectations. } \\
\text { Therefore, the main aim of this study is to evaluate the role of the regional activity } \\
\text { center of Selong Subdistrict in East Lombok on its supporting area (Hinterland).The } \\
\text { research uses descriptive method with reference to the criteria of analysis regions } \\
\text { Central Regional Activities and the index of gravity and Williamson index. The results } \\
\text { showed that Selong has met most of the criteria as Central Regional Activities in East } \\
\text { Lombok. Three factors (of 4 factors) the benchmark has been able to fulfill that is a } \\
\text { factor of Transportation, Economy and Education. While the health factors remain } \\
\text { unaddressed due to the absence Hospital with type B. Geographically, districts most } \\
\text { powerful interactions with Selong District of Sukamulia, followed Labuhan Haji and } \\
\text { weakest interaction District of East Sakra. Selong city generally has a positive effect } \\
\text { (spread effect) against local supporters. Measured by Williamson Index, the average } \\
\text { value below 0.5 where the District Sukamulia with a value of 0.25 has the strongest } \\
\text { effect, while the District of Sakra relatively weak with an index of 0.31. With these } \\
\text { results, to maintain and preserve the existence as Central Regional Activities Selong, } \\
\text { East Lombok local governments need to continue to improve supporting facilities, } \\
\text { especially health facility. }\end{array}$ \\
\hline ABSTRAK : Setap daerah mempunyai kewenangan menentukan pusat kegiatan
\end{tabular}

Kata Kunci :

Daerah pendukung,

pengaruh positif, pusat kegiatan wilayah.

Corresponding Author :

ABSTRAK : Setiap daerah mempunyai kewenangan menentukan pusat kegiatan wilayahnya untuk mempercepat pembangunannya. Setelah penetapan dan pelaksanaannya, maka menjadi penting untuk menilai apakah rencana tersebut sudah sesuai dengan harapan. Untuk itu tujuan utama dari kajian ini adalah mengevaluasi peran pusat kegiatan wilayah Kecamatan Selong Lombok Timur terhadap daerah pendukungnya (Hinterland). Penelitian menggunakan metode deskriptif dengan analisis mengacu pada kriteria daerah pusat kegiatan wilayah dan indeks gravitasi serta Indeks Williamson. Hasil penelitian menunjukkan bahwa Selong telah memenuhi sebagian besar kriteria sebagai pusat kegiatan wilayah di Lombok Timur. Tiga faktor (dari 4 faktor) yang menjadi tolok ukur sudah mampu dipenuhi yaitu faktor perhubungan, perekonomian, dan pendidikan. Sedangkan faktor kesehatan masih belum terpenuhi karena belum adanya rumah sakit dengan tipe B. Secara geografis, kecamatan paling kuat interaksinya dengan Selong adalah Kecamatan Sukamulia, disusul Labuhan Haji dan interaksi paling lemah adalah Kecamatan Sakra Timur. Karena itu secara umum Kecamatan Selong telah memberikan efek positif (spread effect) terhadap daerah pendukungnya. Diukur dari Indeks Williamson, nilai rata-ratanya di bawah 0,5 di mana Kecamatan Sukamulia memiliki nilai 0,25 sehingga efeknya paling kuat, sedangkan Kecamatan Sakra relatif lemah dengan indeks 0,31. Dengan hasil tersebut, untuk menjaga dan mempertahankan eksistensi Selong sebagai Pusat Kegiatan Wilayah, Pemerintah Daerah Lombok Timur perlu terus meningkatkan fasilitas-fasilitas pendukung, terutama fasilitas kesehatan.

Alamat : Program Studi Ekonomi Pembangunan, Fakultas Ekonomi dan Bisnis, Universitas Mataram, Jln. Majapahit No. 62 Mataram.

e-mail: Hailuddin@unram.ac.id 


\section{PENDAHULUAN}

\section{Latar Belakang}

Pembangunan wilayah merupakan proses dalam mengelola sumber daya yang ada dengan tujuan menciptakan lapangan pekerjaan yang akan mendorong pertumbuhan ekonomi wilayah tersebut. Tentu tujuan akhirnya adalah terciptanya kesejahteraan masyarakat, yang memenuhi aspek pemerataan (equalization), pertumbuhan (growth), dan proses berkelanjutan (sustainability). Untuk mencapai tujuan tersebut, pemerintah daerah dan masyarakat harus bekerja sama dalam penggunaan sumber daya yang ada dan mampu menaksir potensi yang dimiliki daerah. Oleh karena itu daerah harus mampu mengidentifikasi sektor potensial yang dimiliki, kemudian menganalisisnya untuk membuat sektor tersebut memiliki nilai tambah bagi pembangunan daerah.

Pembangunan daerah tidak lepas dari pengembangan tata ruang suatu wilayah. Keterkaitan keduanya menunjukkan bahwa perencanaan penataan ruang berkedudukan strategis untuk melandasi tahap-tahap berikutnya. Untuk itulah, perencanaan penataan ruang perlu dilaksanakan secara cermat untuk memperoleh hasil yang optimal.

Perencanaan tata ruang wilayah pada dasarnya adalah menetapkan bagian-bagian wilayah (zona) yang diatur penggunaannya (jelas peruntukannya) dan ada bagian-bagian wilayah yang kurang/tidak diatur penggunannya. Bagi wilayah yang tidak diatur penggunaannya maka pemanfaatannya diserahkan kepada mekanisme pasar. Intinya perencanaan pemanfaatan ruang wilayah harus memberikan kemakmuran yang sebesar-besarnya kepada masyarakat baik dalam jangka pendek maupun jangka panjang termasuk menunjang daya pertahanan dan terciptannya keamanan. Sedangkan cakupan perencanaan ruang wilayah itu sendiri dibagi ke dalam dua kategori, yaitu perencanaan yang mencakup keseluruhan wilayah perkotaan dan non perkotaan (wilayah belakang) dan perencanaan yang khusus untuk wilayah perkotaan.

Perencanaan tata ruang yang menyangkut keseluruhan wilayah misalnya Rencana Tata Ruang Wilayah Nasional
(RTRWN), Rencana Tata Ruang Wilayah Provinsi (RTRWP), dan Rencana Tata Ruang Wilayah Kabupaten (RTRWK). Perbedaan utama dari jenis perencanaan tersebut adalah pada perbedaan kegiatan utama yang terdapat pada wilayah perencanaan. Pada perencanaan keseluruhan wilayah ada kegiatan perkotaan dan ada kegiatan non perkotaan dengan fokus utama menciptakan hubungan yang serasi antara kota dengan wilayah belakangnya. Pada perencanaan wilayah kota, kegiatan utama adalah kegiatan perkotaan dan pemukiman sehingga yang menjadi fokus perhatian adalah keserasian hubungan antara berbagai kegiatan di dalam kota untuk melayani kebutuhan masyarakat perkotaan itu sendiri plus kebutuhan masyarakat yang datang dari luar kota.

Kebijakan pembangunan perkotaan harus diikuti oleh pembangunan infrastruktur, transportasi, komunikasi, dan kelembagaan sosial yang secara alami dapat meningkatkan daya tarik investasi. Implikasinya terhadap kegiatan ekonomi yang terjadi di masyarakat adalah bagaimana hasil produksi dari pusatpusat pertumbuhan tersebut, dapat dipakai untuk melaksanakan kegiatan ekonomi yang berada di daerah sekitar pusat pertumbuhan (hinterland), sedangkan sisi lainnya adalah produksi hasil daerah hinterland tersebut juga dipakai untuk kegiatan ekonomi yang ada di pusat pertumbuhan. Kondisi ini akan menciptakan hubungan timbal balik yang akan menjadi akselerator bagi pertumbuhan perekonomian daerah.

Secara geografis, pusat pertumbuhan merupakan lokasi yang banyak memiliki fasilitas dan kemudahan sehingga menjadi pusat daya tarik (pole of attraction), yang menyebabkan berbagai macam usaha tertarik untuk berlokasi di daerah tersebut dan masyarakat senang datang memanfaatkan fasilitas yang ada di kota tersebut, walaupun kemungkinan tidak ada interaksi antara usaha-usaha tersebut (Tarigan, 2005). Setiap pusat pertumbuhan memiliki daerah belakang atau wilayah pengaruhnya. Makin besar suatu kota, makin beragam fasilitas yang disediakan sehingga makin luas wilayah pengaruhnya. Suatu kota yang besar selain memiliki daerah belakang yang berupa daerah pertanian, juga beberapa kota kecil. 
Kota kecil biasanya berbentuk kecamatan yang ada pada tiap kota atau kabupaten yang memiliki potensi untuk dikembangkan sebagai pusat pertumbuhan. Selain itu kecamatan tidak memiliki daerah yang terlalu luas, sehingga fungsi pusat pertumbuhan diharapkan dapat dirasakan oleh daerah di sekitarnya. Di kecamatan juga terjadi kegiatan-kegiatan ekonomi, baik itu primer, sekunder maupun tersier. Dengan fasilitas yang tersedia untuk melakukan kegiatan-kegiatan tersebut, diharapkan kecamatan yang ada dapat lebih maju jika ditetapkan sebagai pusat pertumbuhan.

Di sisi lain peran pusat pertumbuhan tidak hanya memiliki dampak positif, tetapi juga bisa negatif. Kondisi demikian akan terjadi jika perkembangan ekonomi diserahkan pada mekanisme pasar di mana terdapat pemusatan kegiatan ekonomi di daerah-daerah tertentu. Pemusatan kegiatan ekonomi di suatu daerah bisa mempunyai pengaruh yang merugikan (backwash effects) bagi daerah-daerah lain, dikarenakan tenaga kerja yang ada, modal, perdagangan akan pindah ke daerah yang menjadi pusat kegiatan ekonomi tersebut. Namun di sisi lain ada juga keuntungan bagi daerah-daerah di sekitar di mana ekspansi ekonomi terjadi, misalnya terjualnya hasil produksi daerah, adanya kesempatan kerja baru, dan sebagainya. Pengaruh yang menguntungkan karena adanya ekspansi ekonomi suatu daerah ke daerah sekitarnya dinamakan spread effects (Adisasmita, 2005).

Jika unsur spread effects ini lebih besar dibandingkan dengan backwash effects tentu tidak menjadi masalah. Namun pada beberapa daerah miskin, spread effects yang terjadi jauh lebih kecil daripada backwash effects-nya sehingga secara keseluruhan ekspansi daerah kaya akan memperlambat pembangunan daerah miskin. Akibatnya bisa diduga bahwa jurang kesejahteraan antara kedua daerah tersebut akan semakin melebar (Arsyad, 2000).

Kabupaten Lombok Timur sebagai bagian dari Provinsi Nusa Tenggara Barat memiliki beberapa kecamatan yang mampu mendorong pembangunan daerahnya. Kecamatan Selong merupakan pusat perekonomian dan pemerintahan dan sekaligus sebagai ibu kota Kabupaten. Berdasarkan Perda NTB No 3 Tahun 2010 tentang Rencana Tata Ruang Wilayah Provinsi (RTRWP) Tahun 2009-2029 (Pemprov. NTB, 2010), Kecamatan Selong telah ditetapkan sebagai Pusat Kegiatan Wilayah (PKW), dengan kawasan perkotaannya yang berfungsi untuk melayani kegiatan skala provinsi atau beberapa kabupaten lainnya.

Kriteria suatu Pusat Kegiatan Wilayah (PKW) antara lain : (1) kawasan perkotaan yang berfungsi atau berpotensi sebagai simpul kedua kegiatan ekspor impor yang mendukung Pusat Kegiatan Nasional (PKN); (2) kawasan perkotaan yang berfungsi atau berpotensi sebagai pusat kegiatan industri dan jasa yang melayani skala provinsi atau beberapa kabupaten; dan (3) kawasan perkotaan yang berfungsi atau berpotensi sebagai simpul transportasi yang melayani skala provinsi atau beberapa kabupaten, (Pemprov. NTB, 2010).

Selong sebagai ibu kota kabupaten sekaligus sebagai salah satu kecamatan yang ada di Lombok Timur merupakan wilayah pusat pertumbuhan dan juga pusat kegiatan pembangunan daerah. Kecamatan ini berbatasan langsung dengan beberapa kecamatan sekitarnya seperti Kecamatan Sukamulia, Suralaga, Sakra, Sakra Timur, dan Kecamatan Labuhan Haji, sebagai kecamatan pendukung (hinterland) dan sekaligus sebagai mitra kerja pembangunan wilayah.

Dengan posisi sebagai ibu kota kabupaten, tentu Selong memiliki perkembangan yang lebih baik dalam bidang sarana dan prasarana pembangunan, sumber daya manusia, perekonomian, hiburan, dan lain-lainnya. Kelebihan-kelebihan tersebut, semuanya tentu akan memberi dampak yang langsung maupun tidak langsung terhadap daerah sekitarnya terutama wilayah/kecamatan terdekatnya/pendukung. Namun dampak-dampak demikian biasanya tidak selamanya bersifat positif (spread effects), adakalanya membawa pengaruh negatif (backwash effects). Hal ini disebabkan interaksi penduduk antar-wilayah yang intensif, yang pada akhirnya akan berkontribusi terhadap pertumbuhan ekonomi regional suatu daerah. Namun demikian pengaruh tersebut sangat 
tergantung bagaimana penduduk yang ada di wilayah tersebut, apakah bekerja secara efisien atau tidak. (Widarjono dalam Mauleny, 2015).

Dengan gambaran tersebut permasalahan dari kajian ini adalah, apakah Kecamatan Selong sudah tepat sebagai pusat pertumbuhan sesuai kriteria yang ditetapkan (Perda NTB No 3 Tahun 2010 tentang Rencana Tata Ruang Wilayah Provinsi (RTRWP) Tahun 2009-2029. Selain itu, apakah yang menjadi daya tarik Kecamatan Selong terhadap daerah lain di sekitarnya, serta apakah Kecamatan Selong sebagai pusat pertumbuhan berkontribusi bersifat spread effects atau backwash effects terhadap daerah sekitarnya. Dengan dasar itulah penelitian ini menjadi semakin bermakna untuk dikaji lebih mendalam.

Terkait dengan hal tersebut, kajian ini bertujuan untuk menganalisis dan mengetahui kesesuaian Kecamatan Selong sebagai pusat pertumbuhan yang telah ditetapkan. Selain itu untuk mengetahui apa yang menjadi daya tarik kecamatan ini sebagai pusat pertumbuhan terhadap daerah lain di sekitarnya. Di samping itu untuk mengetahui perannya sebagai pusat pertumbuhan wilayah, apakah sudah mampu berkontribusi positif (spread effects) atau negatif (backwash effects) pada daerah pendukungnya.

\section{KAJIAN PUSTAKA}

a. Pusat Wilayah

Pada dasarnya pembagian wilayah berdasarkan pusat wilayah pinggiran (centre-periphery). Meskipun ini merupakan klasifikasi dasar, tetapi dapat dianggap sangat kasar sebagai kerangka kebijakan yang bermanfaat untuk pengembangan wilayah. Richardson (dalam W. Suprihatin dan Hailuddin, 2016), membuat klasifikasi berdasarkan tingkat kemakmuran dan kemampuan berkembang masing-masing wilayah. Tingkat kemakmuran dinyatakan dengan pendapatan regional per kapita, dan kemampuan berkembang dicerminkan oleh laju pertumbuhan pembangunan. Berdasarkan kriteria tersebut, wilayah dapat diklasfikasikan menjadi 4 kelompok, yaitu;

1. Wilayah-wilayah yang berpendapatan per kapita rendah dan kurang berkembang atau low per capita income and stagnant regions (LS).

2. Wilayah-wilayah yang berpendapatan per kapita tinggi tetapi kurang berkembang atau high per capita income and stagnant regions (HS).

3. Wilayah-wilayah yang berpendapatan per kapita rendah tetapi berkembang atau low per capita income and growth regions (LG).

4. Wilayah-wilayah yang berpendapatan per kapita tinggi dan berkembang atau high per capita income and growth regions (HG). (Adisasmita, 2008).

Klasifikasi di atas dapat digunakan untuk mengetahui sejauh mana pengaruh mobilitas internal sumber daya penduduk, modal, dan faktor-faktor produksi lainnya. Demikian pula arus perdagangan antarwilayah, apakah akan memberikan manfaat atau sebaliknya akan menimbulkan hambatan dalam pertumbuhan wilayah, baik di wilayah asal maupun di wilayah tujuan.

Salah satu pusat wilayah yang dapat berkontribusi dalam pertumbuhan wilayah lainnya adalah kota. Perkembangan kota sangat berkorelasi dengan perkembangan infrastruktur dan fasilitas yang ada (Kuncoro, 2012). Hal ini mengingat kota merupakan wilayah dengan kepadatan penduduk tinggi, yang sebagian lahannya terbangun, dan perekonomiannya bersifat non pertanian. Di samping itu kota mempunyai, (a) jumlah penduduk yang relatif besar daripada wilayah sekitarnya, (b) mempunyai kepadatan penduduk yang relatif tinggi dibanding wilayah sekitarnya, (c) mempunyai proporsi jumlah penduduk yang bekerja di sektor nonpertanian lebih tinggi dari wilayah sekitarnya, (d) merupakan pusat kegiatan ekonomi yang menghubungkan kegiatan pertanian wilayah sekitarnya dan tempat pemrosesan serta pemasaran bahan baku bagi industri (Gulo, 2015).

b. Pusat Pertumbuhan (Growth Pole)

Pusat pertumbuhan (growth pole) mulamula dikemukakan oleh Perroux (1955), seorang ekonom Prancis. Pemikiran ini muncul sebagai reaksi terhadap 
pandangan para ekonom pada waktu itu (Casel dan Schumpeter dalam Sjafrizal, 2012) yang mengungkapkan bahwa transfer pertumbuhan antar-wilayah umumnya berjalan lancar, sehingga perkembangan penduduk, produksi, dan kapital tidaklah selalu proporsional antarwaktu. Namun kenyataannya transfer pertumbuhan ekonomi antar-daerah umumnya tidaklah lancar, tetapi cenderung terkonsentrasi pada daerahdaerah tertentu yang mempunyai keuntungan-keuntungan lokasi.

Dari hal tersebut terlihat ada empat karakteristik utama sebuah pusat pertumbuhan yaitu: (a) Adanya sekelompok kegiatan ekonomi terkonsentrasi pada suatu lokasi tertentu; (b) Konsentrasi kegiatan ekonomi tersebut mampu mendorong pertumbuhan ekonomi yang dinamis dalam perekonomian; (c) Terdapat keterkaitan input dan output yang kuat antara sesama kegiatan ekonomi pada pusat tersebut, dan; (d) Dalam kelompok kegiatan ekonomi tersebut terdapat sebuah industri induk yang mendorong pengembangan kegiatan ekonomi pada pusat tersebut (Sjafrizal, 2012).

Dari aspek lain pusat pertumbuhan (growth pole) dapat dilihat secara fungsional dan geografis. Secara fungsional, pusat pertumbuhan adalah suatu lokasi konsentrasi kelompok usaha atau cabang industri yang karena sifat hubungannya memiliki unsurunsur kedinamisan sehingga mampu menstimulasi kehidupan ekonomi (baik ke dalam/ke luar). Secara geografis, merupakan suatu lokasi yang memiliki fasilitas dan kemudahan sehingga menjadi pusat daya tarik (pole of attraction), yang menyebabkan berbagai macam usaha tertarik untuk berlokasi di kota itu dan masyarakat sering datang memanfaatkan fasilitas yang ada tersebut, walaupun kemungkinannya tidak ada interaksi antara usaha-usaha tersebut (Tarigan, 2005).

Sejalan dengan ketentuan di atas, di setiap daerah juga sudah menetapkan pusatpusat pertumbuhannya yang disebut Pusat Kegiatan Wilayah (PKW) yang biasanya diatur dengan Peraturan Daerah (Perda). Demikian juga dengan Pemerintah Propinsi NTB telah menetapkan Perda NTB No.3 Tahun 2010 tentang Rencana Tata Ruang Wilayah Provinsi (RTRWP) Tahun 2009-2029 (Pemprov. NTB, 2010), yang menetapkan Pusat Kegiatan Wilayah, dengan ketentuan memiliki standar sarana sebagai berikut :

1. Perhubungan : Bandara Pusat Penyebaran Tersier dan/atau Pelabuhan Regional/

Pengumpan Primer dan/atau Terminal Penumpang Tipe-B.

2. Ekonomi : Pasar Induk Regional, Perbankan Regional atau Nasional.

3. Kesehatan : Rumah Sakit Umum Tipe-B.

4. Pendidikan:Perguruan Tinggi minimal setingkat D-3.

Dengan melihat peran dan posisi strategis pusat pertumbuhan sebagai sarana dan strategi pembangunan wilayah, di mana pembangunan industri merupakan ciri utama untuk menciptakan kutub pertumbuhan, maka pusat pertumbuhan akan sangat menentukan gerak kemajuan pembangunan ekonomi maupun sosial daerah sekitarnya. Perkembangan pusat pertumbuhan beserta daerah kotanya dapat mempunyai pengaruh timbal balik terhadap wilayah belakangnya (hinterland). Pengaruh ini bisa bersifat menguntungkan (spread effects) maupun merugikan (backwash effects) bagi perkembangan wilayah secara keseluruhan.

c. Hinterland

Hinterland (daerah belakang) dalam hal ini mempunyai pengertian: 1)The land directly adjacent to and inland from a coast; 2) A region serve by aport city and its facilities; 3) A region remote from urban areas: back country (Oxford University dalam Thandi, 2010). Jadi yang dimaksud dengan hinterland adalah daerah belakang suatu pelabuhan, di mana luasnya relatif dan tidak mengenal batas administratif suatu daerah, provinsi atau batas suatu negara tergantung kepada ada atau tidaknya pelabuhan yang berdekatan dengan daerah tersebut. Di samping itu jaringan lalu lintas perhubungan darat : jalan raya, kereta api, dan lalu lintas sungai memegang peranan penting pula untuk daerah belakang tersebut.

Hinterland tentu memiliki interaksi yang kuat dengan pusat pertumbuhan (growth pole) yang biasanya wilayah perkotaan. Hal ini terkait dengan gerak laju pertumbuhan 
sektor ekonomi terutama sektor yang memiliki peranan dominan, di mana hal ini akan berpengaruh terhadap perkembangan jumlah penduduk disertai dengan mobilitasnya yang semakin meningkat, sehingga perkembangan jumlah penduduk tersebut akan menyebabkan terjadinya perubahan terhadap hirarki dan fungsi kota. Adanya peningkatan hirarki serta pengembangan fungsi kota memberikan implikasi terhadap kebutuhan prasarana dan sarana perkotaan untuk mendukungnya.

Beberapa fungsi kota sebagai bagian dari hinterland antaranya, a) Kota utama, yang berperan sebagai pusat-pusat pertumbuhan, dan b) Kota kedua, yang melayani wilayah sub regional dan menjembatani antara kota-kota utama dan kota-kota kecil, (Purnamaningsih, 2009).

d. Teori Lokasi dan Model Gravitasi

Teori lokasi merupakan teori dasar yang sangat penting dalam analisa spasial di mana tata ruang dan lokasi kegiatan ekonomi merupakan unsur utama. Teori lokasi memberikan kerangka analisa yang baik dan sistematis mengenai pemilihan lokasi kegiatan ekonomi dan sosial serta analisa interaksi antarwilayah atau antarkota. Teori ini menjadi penting dalam analisa ekonomi karena pemilihan lokasi yang baik akan dapat memberikan penghematan yang sangat besar untuk ongkos angkut sehingga mendorong terjadinya efisiensi baik dalam bidang produksi maupun pemasaran. Sedangkan interaksi antar-wilayah akan dapat pula memengaruhi perkembangan bisnis yang pada gilirannya akan dapat pula mendorong pertumbuhan ekonomi wilayah bersangkutan (Sjafrizal, 2012).

Sebagai kesatuan wilayah, kota merupakan suatu sistem jaringan kehidupan manusia yang ditandai dengan kepadatan penduduk yang tinggi dengan strata sosial ekonomi yang heterogen dan coraknya yang materialistik atau sebagai bentang budaya yang ditimbulkan oleh unsur-unsur alami dan non-alami dengan gejala-gejala pemusatan penduduk yang cukup besar dengan corak kehidupan yang heterogen dan materialistik dibandingkan dengan daerah belakangnya.

Di samping itu sebagai suatu wadah interaksi masyarakat, kota memiliki unsur-unsur pendukung antaranya adalah :

a. Unsur-unsur fisis, yaitu topografi dan kesuburan tanah serta iklim yang cocok untuk tempat tinggal.

b. Unsur-unsur ekonomi, yaitu fasilitasfasilitas yang dapat memenuhi kebutuhan primer warga kota.

c. Unsur-unsur sosial, yang dapat menimbulkan keserasian, ketenangan hidup warga kota.

d. Unsur-unsur kultural, seni, dan kebudayaan memberikan semangat dan gairah hidup kota.

e. Unsur teknologi, semakin pesat perkembangan teknologi maka semakin pesat pula perkembangan kota.

Setiap kota memiliki unsur fisis, ekonomi, sosial, dan kultur yang berbeda. Perbedaan ini dibentuk oleh interaksi masyarakat dan lingkungan tempat tinggal. Sumber daya alam yang ada menjadi penopang kelangsungan hidup masyarakat setempat. Sama halnya dengan karakteristik yang dimiliki oleh suatu kota.

Selanjutnya dalam geografi, interaksi diartikan sebagai interaksi geografis antarsatu wilayah dengan wilayah lain. Begitu juga halnya dengan kota satu dengan kota lainnya. Semakin banyak perbedaan yang ada maka peluang menciptakan interaksi antara keduanya makin besar.

Permodelan yang dapat digunakan dalam melakukan analisis terhadap pola interaksi atau keterkaitan antar-daerah atau antar-bagian wilayah dengan wilayah lainnya adalah Model Gravitasi. Penerapan model ini dalam bidang analisis perencanaan kota adalah dengan anggapan dasar bahwa faktor aglomerasi penduduk, pemusatan kegiatan atau potensi sumber daya alam yang dimiliki, mempunyai daya tarik yang dapat dianalogikan sebagai daya tarik menarik antara 2 (dua) kutub magnet.

Namun ada kelemahan penerapan model ini dalam analisis wilayah, terutama terletak pada variabel yang digunakan sebagai alat ukur, di mana dalam fisika variabel yang digunakan, yaitu molekul suatu zat 
mempunyai sifat yang homogen, namun tidak demikian halnya dengan unsur pembentuk kota, misalnya penduduk. Meski demikian, hal ini telah dikembangkan, yaitu dengan tidak hanya memasukan variabel massa saja, tetapi juga gejala sosial sebagai faktor pembobot.

Perbedaan karakteristik antara dua kota atau dua wilayah akan menyebabkan terjadinya keterkaitan di antara kedua kota atau kedua wilayah tersebut. Intensitas keterkaitan yang terjadi akan sangat ditentukan oleh tipe keterkaitan yang berlaku di antara kedua kota atau wilayah tersebut. Intensitas keterkaitan ini salah satunya berdampak interaksi yang terjadi antara dua kota tersebut. Karakteristik kota yang saling bertolak belakang di antara keduanya mengakibatkan tingginya intensitas keterkaitan.

Interaksi wilayah (Spatial Interaction) adalah hubungan timbal balik yang saling memengaruhi antara dua wilayah atau lebih, yang dapat melahirkan gejala, kenampakan, dan permasalahan baru baik secara langsung maupun tidak langsung. Interaksi ini berupa perilaku dari pihak-pihak yang bersangkutan melalui kontak langsung atau melalui media.

Interaksi ini juga bisa menimbulkan ketimpangan antar-wilayah dalam pembangunannya. Jeffrey G. Williamson (1966) menunjukkan formulasi cara mengukur tingkat ketimpangan pembangunan antarwilayah (Kuncoro, 2003). Berbeda dengan Gini Ratio yang lazim digunakan dalam mengukur distribusi pendapatan antar-golongan masyarakat. Williamson Index menggunakan Produk Domestik Regional Bruto (PDRB) per kapita sebagai data dasar. Alasannya jelas karena yang diperbandingkan adalah tingkat pembangunan antar-wilayah dan bukan tingkat distribusi pendapatan antar-kelompok masyarakat.

\section{METODE PENELITIAN}

Kajian ini berdasarkan pada penelitian deskriptif kuantitatif, yang intinya mempelajari masalah-masalah dalam masyarakat, serta tata cara yang berlaku dalam masyarakat serta situasi-situasi tertentu, termasuk tentang hubungan kegiatan, sikap, pandangan, serta proses- proses yang sedang berlangsung dan pengaruh dari suatu fenomena (Sugiyono, 2012). Oleh karena itu secara mendalam akan mengkaji berbagai hal yang terkait interaksi antara pusat pertumbuhan wilayah di Lombok Timur (Selong) dengan daerah pendukungnya. Interaksi ini tentu dalam berbagai aspek kegiatan, baik ekonomi, sosial, budaya, dan sumber daya masyarakat lainnya.

Lokasi kajian adalah Kabupaten Lombok Timur, di mana ibu kotanya (Kecamatan Selong) telah ditetapkan sebagai salah satu pusat pertumbuhan wilayah di Lombok Timur. Kecamatan ini berbatasan langsung dengan 5 (lima) kecamatan pendukungnya, seperti Kecamatan Sukamulia, Suralaga, Sakra, Sakra Timur, dan Labuhan Haji. Jarak masing-masing kota kecamatan pendukung ke pusat perumbuhan wilayah (Selong) bervariasi antara $4 \mathrm{~km}$ sampai dengan $18 \mathrm{~km}$.

Jenis data yang digunakan adalah data kuantitatif, yaitu data PDRB, pendapatan per kapita, data geografis, jumlah penduduk, jarak antar-wilayah, data pendidikan, perekonomian, sarana transportasi, sarana kesehatan, dan lain-lain. Sumber datanya adalah dari Badan Pusat Statistik (BPS) Provinsi NTB, BPS dan Badan Perencanaan Pembangunan Daerah (BAPPEDA) Kabupaten Lombok Timur, dan sumber data on-line. Sedangkan pengumpulannya dilakukan dengan observasi langsung, dengan mengkaji dan membaca, mengumpulkan, mencatat data-data, informasi, dan keterangan. Sementara data yang dikumpulkan merupakan data hasil olahan dari sumbersumber di atas.

A. Variabel Pendukung

Berdasarkan kebutuhan analisis, maka variabel-variabel yang diidentifkasi yang menjadi tolok ukur suatu Pusat Kegiatan Wilayah adalah:

\section{Perhubungan}

Dalam hal ini merupakan segala hal yang berkaitan dengan lalu lintas dan telekomunikasi (jalan, pelayaran, penerbangan, dan pos). Standar infrastruktur minimal untuk Pusat Kegiatan Wilayah bidang ini adalah ketersediaan sarana-sarana seperti: bandara, dan/atau pelabuhan regional, 
dan/atau terminal penumpang dengan kualifikasi/tipe B.

2. Perekonomian

Untuk faktor perekonomian adalah segala hal yang berkaitan dengan produksi, distribusi, dan konsumsi barang dan jasa. Standar infrastruktur minimal untuk sarana penunjang kegiatan pekonomian ini adalah keberadaan pasar induk regional, dan perbankan regional dan/atau nasional.

3. Kesehatan

Dalam bidang kesehatan, acuannya adalah segala hal yang berkaitan dengan keadaan dan kesejahteraan badan, jiwa, dan sosial setiap orang. Oleh karena itu dalam penelitian ini, tolok ukur bidang kesehatan yang dipakai yaitu ketersediaan/keberadaan rumah sakit umum (RSU) dengan standar minimal kualifikasi/tipe-B.

4. Pendidikan

Pendidikan adalah segala hal yang berkaitan dengan proses pembelajaran, pengetahuan, keterampilan, dan kebiasaan penduduk. Tolok ukurnya berkaitan dengan fasilitas penunjang pendidikan yang dimiliki oleh suatu daerah. Standar infrastruktur minimal bidang pendidikan ini adalah keberadaan perguruan tinggi setingkat Diploma-3 di daerah analisis.

5. Jarak Antar-wilayah

Jarak adalah panjang garis dari suatu titik ke titik lainnya. Sehingga dalam penelitian ini jarak yang dimaksud adalah panjang garis titik dari Kecamatan Selong ke kecamatan lain di sekitarnya/pendukung yang menjadi kajian. Satuan yang dipakai dari variabel jarak disini adalah kilometer (km).

6. Penduduk

Penduduk adalah seluruh orang yang berdomisili di wilayah geografis selama 6 bulan atau lebih dan atau mereka yang berdomisili kurang dari 6 bulan tetapi bertujuan untuk menetap di daerah penelitian dengan satuan orang/jiwa.

7. Produk Domestik Regional Bruto (PDRB) Produk Domestik Regional Bruto (PDRB) merupakan jumlah nilai tambah yang timbul dari semua unit produksi di dalam suatu wilayah dalam jangka waktu tertentu. PDRB yang digunakan dalam penelitian ini adalah PDRB atas dasar harga konstan tahun 2010 dalam satuan juta rupiah.

8. Pendapatan Per Kapita

Merupakan pendapatan rata-rata penduduk suatu daerah pada periode tertentu. Pendapatan per kapita dihitung dengan cara membagi jumlah PDRB suatu daerah dengan jumlah penduduk daerah tersebut. Satuan variabel pendapatan per kapita adalah juta rupiah.

\section{ANALISIS DATA}

1. Faktor Perhubungan, Ekonomi, Kesehatan, dan Pendidikan

Untuk faktor perhubungan, ekonomi, kesehatan, dan pendidikan dianalisis dengan menggunakan metode kuantitatif deskriptif, dengan mengkaji dan menggambarkan berbagai sarana dan prasarana pendukung yang tersedia sesuai dengan standar yang ditetapkan dalam Peraturan Daerah Provinsi NTB No.3 Tahun 2010 tentang Rencana Tata Ruang Wilayah Provinsi (RTRWP) Tahun 2009-2029.

2. Model Gravitasi

Model ini untuk menganalisis perencanaan kota yang menganggap bahwa faktor aglomerasi penduduk, pemusatan kegiatan atau potensi sumber daya alam yang dimiliki, mempunyai daya tarik yang dapat dianalogikan sebagai daya tarik menarik antara 2(dua) kutub magnet. Kuat lemahnya tingkat interaksi antara dua daerah akan terlihat dari tinggi rendahnya angka indeks gravitasi daerah tersebut.

Formulasi model Gravitasi (Daryanto dan Hafizrianda, 2010) ini adalah:

$$
T_{i j}=\frac{P_{i} x P_{j}}{D_{i j}{ }^{2}}
$$

Di mana:

Tij = pergerakan penduduk tempat $i$ ke tempat $j$

Pi = jumlah penduduk di tempat $i$

Pj = jumlah penduduk di tempat $j$

Dij = jarak antara tempat $i-$ tempat $j$

3. Indeks Williamson 
Indeks ini dipakai untuk mengukur perbandingkan tingkat pembangunan antar-wilayah. Artinya apakah daerah pusat pertumbuhan mampu memberikan peranan terhadap daerah sekitarnya atau terjadi sebaliknya.

Formulasi Indeks Williamson (Kuncoro, 2003), adalah sebagai berikut:

$$
V w=\frac{\sqrt{(y i-y)^{2}(f i / n)}}{y} \text { acuannya; } 0<
$$
$\mathrm{V}_{\mathrm{w}}<$

Di mana:

$$
\begin{aligned}
& V w=\text { Indeks Williamson } \\
& y i=\text { PDRB per kapita daerah } \\
& y=\text { PDRB per kapita rata-rata seluruh } \\
& \quad \text { daerah } \\
& f_{i}=\text { Jumlah penduduk daerah } \mathrm{i} \\
& \mathrm{n}=\text { Jumlah penduduk seluruh daerah }
\end{aligned}
$$

Subskrip w digunakan karena formulasi yang dipakai adalah secara tertimbang (weighted) agar indeks tersebut menjadi lebih stabil dan dapat dibandingkan dengan negara atau daerah lainnya.
Sedangkan kriteria nilai indeks ini adalah: bila $V_{w}$ mendekati 1 berarti daerah itu sangat timpang dan bila $\mathrm{V}_{\mathrm{w}}$ mendekati nol berarti sangat merata.

\section{HASIL DAN PEMBAHASAN}

1. Gambaran Umum Lombok Timur Kabupaten Lombok Timur sebagai salah satu kabupaten di Propinsi Nusa Tenggara Barat memiliki luas wilayah keseluruhan 2.679,88 $\mathrm{km}^{2}$, dengan luas daratan 1.605,55 $\mathrm{km}^{2} \quad(59,91$ persen $)$ dan lautan 1.074,33 $\mathrm{km}^{2} \quad(40,09$ persen). Kabupaten ini terdiri dari 20 kecamatan dengan 245 desa/kelurahan. Kecamatan Aikmel merupakan kecamatan dengan jumlah desa terbanyak yaitu 24 desa dan Kecamatan Sembalun memiliki jumlah desa paling sedikit yaitu 6 desa (BPS Lombok Timur, 2016).

Posisi Kabupaten Lombok Timur di Pulau Lombok berdasarkan wilayah kecamatan masing-masing terlihat dalam gambar sebagai berikut.

Gambar 1. Peta Wilayah Lombok Timur Per Kecamatan Tahun 2016.

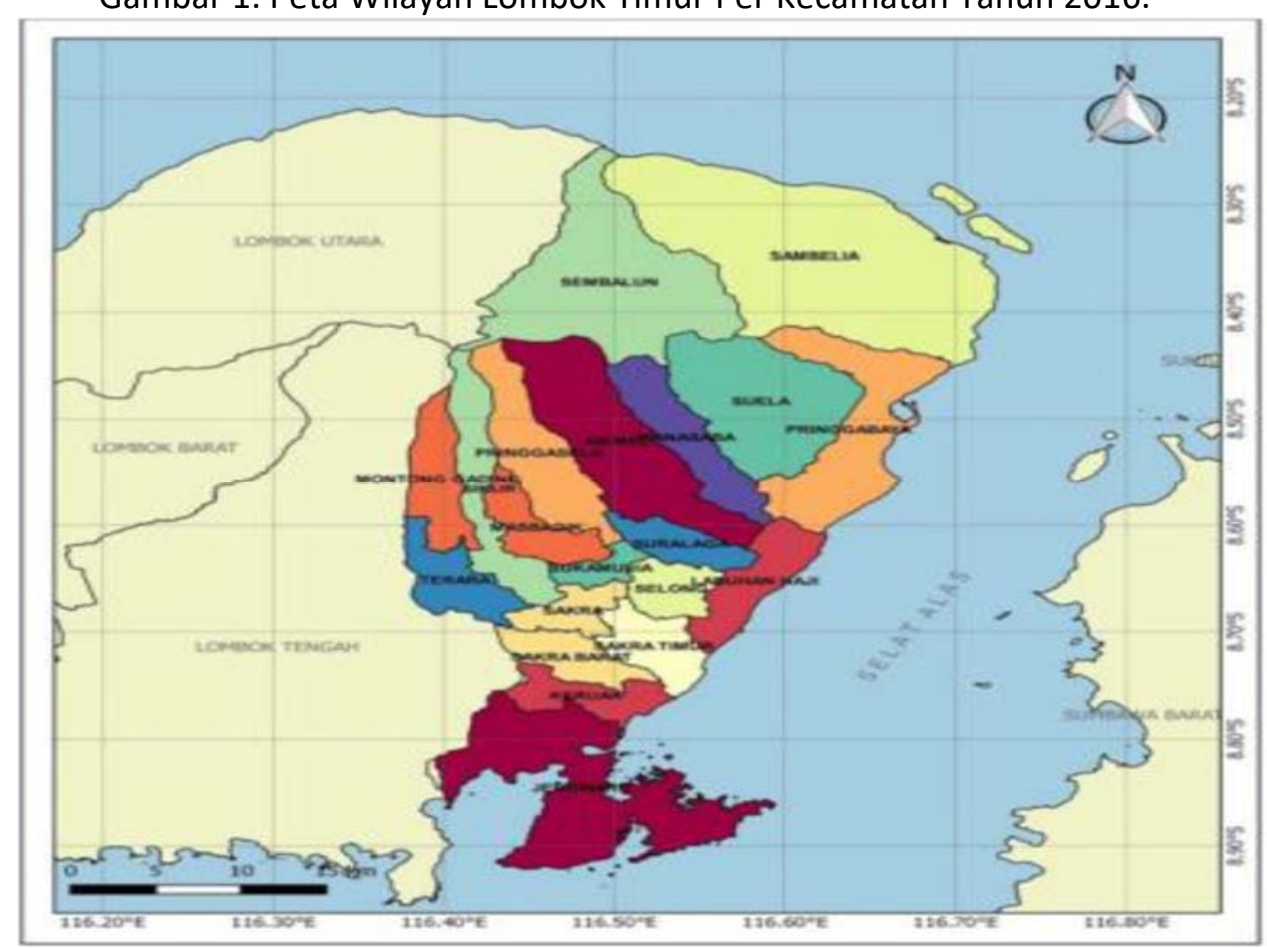

Sumber : BPS. Lombok Timur, 2016

Berdasarkan gambar tersebut, luas wilayah masing-masing kecamatan bervariasi.
Kecamatan Sambelia memiliki wilayah paling luas yaitu 15,27 persen $\left(245,22 \mathrm{~km}^{2}\right)$ dari luas 
Lombok Timur, disusul oleh Kecamatan Sembalun dengan 13,52 persen, Jerowaru 8,89 persen, Pringgabaya 8,48 persen, Pringgasela 8,36 persen, dan yang paling kecil luas wilayahnya adalah Kecamatan Sukamulia dengan 0,90 persen $\left(14,49 \mathrm{~km}^{2}\right)$. Sedangkan Kecamatan Selong sendiri luasnya sekitar $31,68 \mathrm{~km}^{2}$ (1,97 persen).

Dari sisi jumlah penduduk, Lombok Timur memiliki penduduk 1.164.018 jiwa (lakilaki 537.152 jiwa/46,56 persen dan perempuan 616.621 jiwa $/ 53,44$ persen) dengan tingkat kepadatan rata-rata 725 jiwa $/ \mathrm{km}^{2}$. Di sisi lain kepadatan penduduk antar-kecamatan juga cukup bervariasi. Kecamatan Masbagik merupakan kecamatan terpadat dengan kepadatan rata-rata 2.985 jiwa $/ \mathrm{km}^{2}$, menyusul Kecamatan Selong dengan $2.814 \mathrm{jiwa} / \mathrm{km}^{2}$, dan Kecamatan Sembalun merupakan kecamatan dengan densitas penduduk paling kecil, $90 \mathrm{jiwa} / \mathrm{km}^{2}$.

Struktur ekonomi Kabupaten Lombok Timur masih didominasi oleh 8 sektor (dengan porsi total 82,6 persen), di mana sektor pertanian memberikan kontribusi paling besar dengan 27,9 persen, disusul sektor pedagangan dengan 15,9 persen, konstruksi 11,5 persen, dan sisanya 17,4 persen dari sektor lainnya (gambar 2). Sedangkan 9 sektor di luar sektor di atas, relatif belum berkembang dengan kontribusi cukup kecil antaranya sektor pengadaan listrik dan gas (0,09 persen), jasa perusahaan (0,11 persen), dan 7 sektor lain. Kalau dilihat dari laju pertumbuhan, sektor jasa keuangan dan asuransi dengan pertumbuhan tertinggi 8,47 persen, disusul sektor perdagangan 7,67 persen; pengadaan listrik dan gas 7,58 persen, transportasi dan pergudangan 6,86 persen serta jasa kesehatan dan kegiatan sosial 6,43 persen. Sedangkan sektor yang paling kecil tingkat pertumbuhannya adalah sektor pertanian (1,79 persen) meskipun kontribusinya pada PDRB paling besar $(27,9$ persen). Namun secara rata-rata pertumbuhan ekonomi Lombok Timur selama 2015 masih relatif baik yaitu sebesar 4,93 persen (BPS Lombok Timur, 2016).

Gambar 2. Kontribusi Sektor Ekonomi Terhadap Perekonomian Lombok Timur Tahun 2016

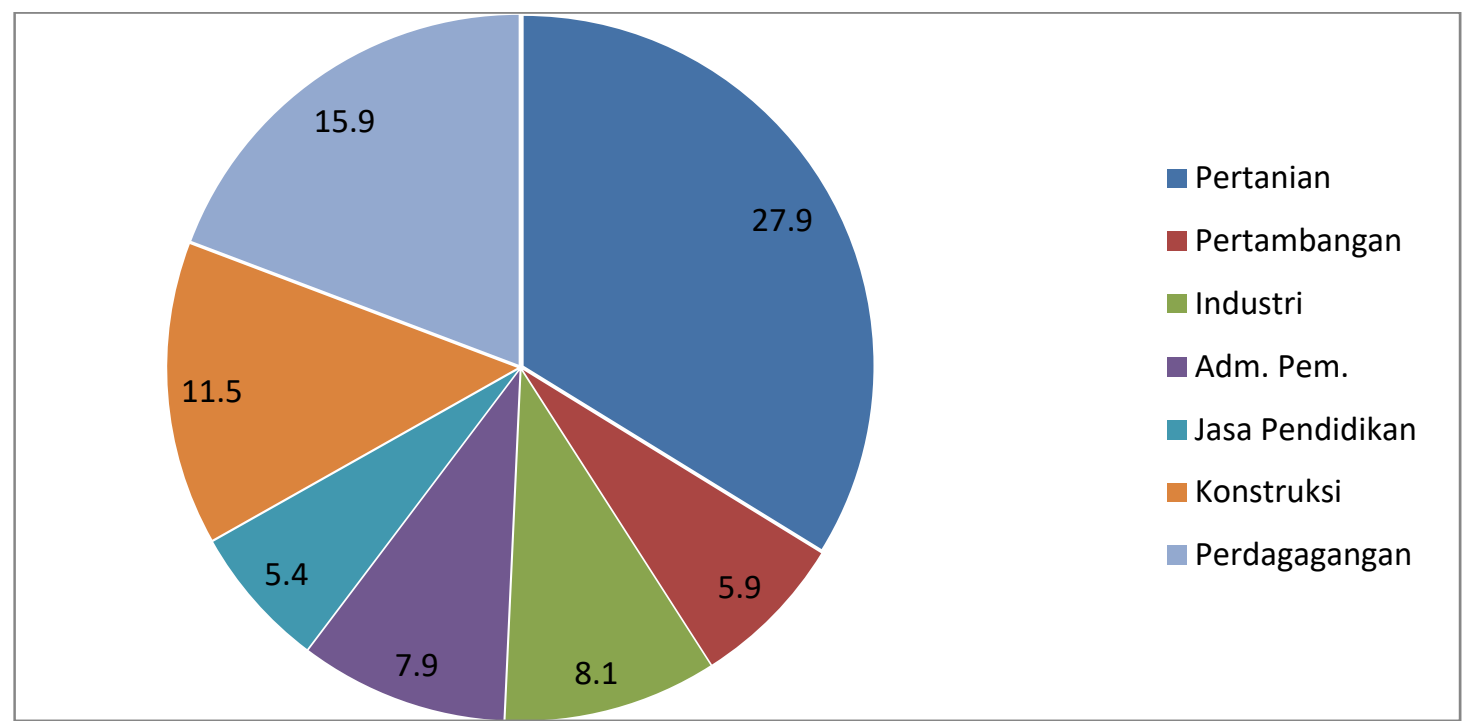

Sumber : BPS. Lombok Timur, 2016

2. Kriteria Pusat Pertumbuhan Wilayah

a). Perhubungan

Tolok ukur faktor perhubungan yang dimaksud dalam hal ini adalah ketersediaan fasilitas perhubungan yang dimiliki Pusat Kegiatan Wilayah baik berupa terminal bus, pelabuhan laut, dan atau bandara. Selong sudah memenuhi salah satu dari sarana yang dipersyaratkan tersebut yaitu terminal bus antarkota. Dengan demikian, dari faktor ini Selong sebagai pusat 
pertumbuhan telah memenuhi kriteria sebagai Pusat Kegiatan Wilayah, karena salah satu syarat telah dipenuhi yaitu memiliki terminal tipe-B. Meskipun untuk fasilitas lain seperti pelabuhan laut dan bandar udara belum ada. Hal ini tentu karena akses Selong ke Bandara Internasional Lombok yang berlokasi di Lombok Tengah relatif mudah dan dekat. Demikian juga untuk pelabuhan laut yang cukup dekat ke Labuhan Haji dengan jarak sekitar $7 \mathrm{~km}$.

b). Perekonomian

Tolok ukur yang digunakan dalam bidang ekonomi adalah ketersediaan fasilitas yang menjadi standar infrastruktur minimal yang harus dimiliki oleh Pusat Kegiatan Wilayah. Dua fasilitas ekonomi yang menjadi acuan penilaian dalam hal ini adalah keberadaan Pasar Induk Regional, serta perbankan regional dan atau nasional. Di Selong sendiri telah ada 1 pasar regional yang didukung oleh 5 pasar tradisional, 7 mini market, dan 1.542 toko kelontong (BPS NTB, 2016). Sedangkan dari aspek ekonomi lainnya yang mesti dipenuhi adalah ketersediaan lembaga perbankan nasional maupun regional. Dalam hal ini juga telah memenuhi syarat karena sudah ada 15 unit bank (11 bank konvensional, 3 bank syariah, dan BPR) yang beroperasi, antaranya Bank BNI, BRI, Mandiri, BTN, BPD, Danamon, dan lain-lain.

c). Kesehatan

Kabupaten Lombok Timur memiliki jumlah sarana dan prasarana kesehatan yang cukup lengkap mulai Posyandu, Poskesdes, Puskesmas sampai tersedianya Rumah Sakit Umum Daerah (RSUD). Sarana dan prasarana kesehatan tersebut tersebar hampir merata di semua kecamatan dan desa. Di Selong sendiri terdapat 3 unit Rumah Sakit Umum, 3 unit Puskesmas, dan 5 Puskesmas Pembantu. Oleh karena itu secara kuantitas, sarana kesehatan yang dimiliki Selong sudah cukup memadai. Meskipun demikian dari aspek ini Selong belum memenuhi kriteria sebagai pusat pertumbuhan, karena belum tersedianya sarana rumah sakit dengan kualifikasi/tipe B. Rumah Sakit Umum Daerah dr. Soedjono sebagai rumah sakit terbesar di Selong, saat ini masih berstatus rumah sakit dengan kualifikasi/tipe $\mathrm{C}$.

d). Pendidikan

Dari aspek ini, Selong telah memiliki lembaga pendidikan yang lengkap mulai tingkat Taman Kanak-Kanak, sampai pendidikan tinggi yang dikelola swasta maupun pemerintah. Khusus untuk pendidikan tinggi Lombok Timur memiliki 11 perguruan tinggi (4 di antaranya ada di Selong) dengan 33 jurusan/program studi, baik tingkat Diploma-3 dan Strata-1. Keseluruhan pendidikan tinggi tersebut sepenuhnya dikelola oleh lembaga swasta. Dengan keberadaan lembaga pendidikan ini, Kecamatan Selong dari aspek pendidikan ini sudah memenuhi syarat sebagai Pusat Kegiatan Wilayah, karena sudah memenuhi standar dengan keberadaan perguruan tinggi ini. Keadaan ini tentunya akan mampu meningkatkan kualitas pendidikan penduduk di Selong maupun daerah lain di sekitarnya (hinterland) yang pada akhirnya akan meningkatkan pembangunan ekonomi di Lombok Timur.

3. Interaksi Kecamatan Selong Terhadap Daerah Pendukung.

a).Daya Tarik Selong Secara Gravitasi Sebagai Pusat Pertumbuhan.

Secara gravitasi hubungan antara daerah yang satu dengan daerah lain diumpamakan dengan hubungan antara massa-massa wilayah yang mempunyai daya tarik sehingga terjadi interaksi. Semakin besar fungsi suatu daerah untuk daerah lainnya maka akan makin kuat hubungan kedua daerah tersebut. Tempattempat yang sarananya lebih lengkap akan memiliki daya tarik yang lebih kuat dibandingkan daerah yang lain. Model Gravitasi akan bisa menggambarkan hubungan tersebut, dengan menggunakan variabel jarak antarwilayah dan interaksi penduduknya. Karena seperti diketahui bahwa pertumbuhan penduduk berpengaruh positif terhadap pertumbuhan ekonomi, (Sheridan dalam Ivon, KN. dkk., 2016). Gambaran jumlah penduduk dan jarak masing-masing kecamatan pendukung ke Selong terlihat dalam tabel berikut. 
Tabel 1 jarak kecamatan selong dan kecamatan pendukung di Lombok Timur

\begin{tabular}{|clcc|}
\hline No & Kecamatan & Jumlah Penduduk & Jarak ke Selong \\
\hline 1 & Sukamulia & 31.581 & 4 \\
\hline 2 & Suralaga & 53.343 & 9 \\
\hline 3 & Sakra & 55.290 & 12 \\
\hline 4 & Sakra Timur & 42.920 & 18 \\
\hline 5 & Labuhan Haji & 55.474 & 7 \\
\hline
\end{tabular}

Sumber: BPS Kabupaten Lombok Timur.

Berdasarkan data di atas dapat dihitung besarnya nilai daya tarik Kecamatan Selong terhadap daerah di sekitarnya, dengan Model Gravitasi. Secara geografis terdapat 5 kecamatan pendukung Kecamatan Selong yaitu Kecamatan Sukamulia, Suralaga, Sakra, Sakra Timur, dan Labuhan Haji. Hasil perhitungan Model Gravitasi antar 5 Kecamatan pendukung dengan Kecamatan Selong seperti terlihat dalam tabel berikut.

Tabel 2. Nilai Indeks Gravitasi Kecamatan Selong Terhadap Kecamatan Pendukung Tahun 2016.

\begin{tabular}{|clc|}
\hline No & Interaksi Antar-kota & Nilai Indeks \\
\hline 1 & Selong - Sukamulia & 173.555 .359 \\
\hline 2 & Selong - Suralaga & 57.906 .131 \\
\hline 3 & Selong - Sakra & 33.761 .072 \\
\hline 4 & Selong - Sakra Timur & 11.647 .879 \\
\hline 5 & Selong - Labuhan Haji & 99.546 .395 \\
\hline
\end{tabular}

Sumber: Data diolah.

Dari hasil perhitungan menunjukkan bahwa Kecamatan Selong memiliki daya tarik yang kuat terhadap daerah belakangnya terutama daerah yang mempunyai jarak cukup dekat. Jarak antar-wilayah merupakan salah satu faktor yang memengaruhi angka indeks gravitasi. Semakin dekat jarak tempuh antara pusat pertumbuhan dengan wilayah hinterland-nya maka semakin tinggi angka indeks gravitasi yang dihasilkan sehingga tingkat interaksi yang dihasilkan akan semakin kuat.

Daerah hinterland yang interaksinya (daya tarik) paling kuat dengan pusat pertumbuhan adalah Kecamatan Sukamulia dengan nilai indeks gravitasi sebesar 173.555.359, disusul Labuhan Haji dengan

indeks 99.546.395, sedangkan interaksi terendah adalah Kecamatan Sakra Timur dengan indeks gravitasi 11.647.879. Hal ini karena Kecamatan Sakra Timur memiliki jarak paling jauh sebagai daerah pendukung pusat pertumbuhan dibandingkan kecamatan lainnya. Interaksi yang tinggi antara pusat pertumbuhan dengan daerah sekitarnya (pendukung) memberikan gambaran mengenai perilaku yang saling memengaruhi antar-kawasan yaitu daerah yang dipengaruhi dan daerah yang memengaruhi. Demikian juga sarana dan prasarana yang ada di pusatpusat pertumbuhan dapat dimanfaatkan penduduk daerah pendukung, sehingga pusat pertumbuhan mempunyai peranan dalam penyediaan pelayanan bagi daerah belakang. Karena itu dalam kegiatan transaksi dan konsumsi antar keduanya akan saling mendukung, mengingat konsumsi yang dilakukan oleh satu orang dalam perekonomian akan menjadi pendapatan untuk orang lain pada perekonomian yang sama (Keynes dalam Amaliah, 2015). Dengan dasar tersebut Kecamatan Selong memiliki fasilitas-fasilitas yang diperlukan oleh daerah pendukungnya dan juga sarana dan prasarananya lebih lengkap dibandingkan daerah pendukung. Oleh karena itu ditinjau dari segi perilaku kawasan menggambarkan tingginya peranan pusat pertumbuhan yang memengaruhi dan dipengaruhi.

b). Kontribusi Kecamatan Selong Sebagai

Pusat Pertumbuhan Wilayah.

Untuk melihat peranan Kecamatan Selong bagi pembangunan ekonomi wilayah dapat 
dilihat dari tingkat ketimpangan pendapatan antara pusat pertumbuhan dengan daerah pendukung. Kesenjangan pendapatan merupakan salah satu indikator tentang efektif atau tidaknya pusat pertumbuhan akan memberikan pengaruh spread effect atau backwash effect terhadap daerah pendukung. Untuk mengukur keadaan tersebut dapat dilihat dari nilai Indeks Williamson, dengan dasar perhitungan nilai PDRB perkapita dan jumlah penduduk, seperti terlihat dalam tabel berikut.

Tabel 3. PDRB dan Jumlah Penduduk Kecamatan Selong dan Kecamatan Pendukung Tahun 2016.

\begin{tabular}{|clcc|}
\hline No & Kecamatan & PDRB & Jumlah Penduduk \\
\hline 1 & Sukamulia & $307.932,55$ & 31.581 \\
\hline 2 & Suralaga & $520.124,31$ & 53.343 \\
\hline 3 & Sakra & $539.108,66$ & 55.290 \\
\hline 4 & Sakra Timur & $418.494,19$ & 42.920 \\
\hline 5 & Labuhan Haji & $540.902,76$ & 55.474 \\
\hline 6 & Selong & $857.357,31$ & 87.929 \\
\hline 7 & Lombok Timur & $11.249 .937,00$ & 1.153 .773 \\
\hline
\end{tabular}

Sumber: BPS Kabupaten Lombok Timur.

Berdasarkan besaran nilai PDRB dan jumlah penduduk pada tahun yang sama di atas, maka dapat dihitung nilai Indeks Williamson masing-masing kecamatan pendukung. Nilai Indeks Williamson berada pada kisaran 0 sampai 1, apabila hasil yang diperoleh mendekati 0 maka ketimpangan pendapatan antar-daerah semakin kecil, begitu juga sebaliknya, apabila hasil yang diperoleh mendekati 1 maka ketimpangannya semakin besar. Dari perhitungan yang dilakukan diperoleh nilai Indeks Williamson pada daerah pusat pertumbuhan (Kecamatan Selong) dan kecamatan pendukung/sekitarnya seperti terlihat pada tabel berikut.

Tabel 4. Hasil Indeks Williamson Kecamatan Selong dan Pendukungnya di Lombok Timur Tahun 2016.

\begin{tabular}{|clc|}
\hline No & Kecamatan & Indeks Williamson \\
\hline 1 & Sukamulia & 0,25 \\
\hline 2 & Suralaga & 0,26 \\
\hline 3 & Sakra & 0,31 \\
\hline 4 & Sakra Timur & 0,29 \\
\hline 5 & Labuhan Haji & 0,28 \\
\hline 6 & Selong & 0,26 \\
\hline & Total & 0,27 \\
\hline
\end{tabular}

Sumber: Data diolah.

Dari data di atas dapat dilihat bahwa kecamatan kajian memiliki hasil Indeks Williamson rata-rata mendekati 0 , ini berarti pertumbuhan ekonomi antar-daerah tersebut relatif merata. Kecamatan Sukamulia yang merupakan kecamatan yang memiliki interaksi terkuat dengan indeks sebesar 0,25, dan merupakan nilai terendah di antara kecamatan pendukung lainnya. Ini artinya Kecamatan Selong telah memberikan spread effect yang kuat terhadap kecamatan pendukung tersebut. Hal itu didukung pula oleh jarak yang dekat antara Kecamatan Selong dengan Kecamatan Sukamulia. Disusul kemudian oleh Kecamatan Suralaga, Labuhan Haji, Sakra Timur, dan Kecamatan Sakra. Namun secara umum dengan nilai Indeks Williamson yang rata-rata rendah $(0,27)$ menggambarkan bahwa Kecamatan Selong mampu memberikan spread effect yang baik 
terhadap wilayah pendukungnya. Dengan pengaruh tersebut akan menciptakan pertumbuhan regional yang baik bagi daerah, sebagaimana diungkapkan Glasson (dalam Permatacita, 2012), bahwa pertumbuhan regional dapat terjadi sebagai akibat dari penentu-penentu endogen ataupun eksogen, yaitu faktor-faktor yang terdapat di dalam daerah yang bersangkutan maupun faktorfaktor di luar daerah, atau kombinasi keduanya.

\section{KESIMPULAN DAN SARAN}

\section{Kesimpulan}

Berdasarkan hasil analisis dapat dijelaskan bahwa mengacu pada standar infrastruktur yang tersedia, kota Selong telah memenuhi sebagian besar kriteria sebagai Pusat Kegiatan Wilayah (PKW) di Kabupaten Lombok Timur. Kondisi ini dapat dilihat dari 4 (empat) kriteria yang dijadikan tolok ukur, 3 (tiga) di antaranya telah dipenuhi. Tiga faktor dimaksud yang telah dicapai adalah faktor ; perhubungan, perekonomian, dan pendidikan. Sedangkan faktor kesehatan tidak memenuhi syarat karena belum adanya rumah sakit dengan klasifikasi/tipe B.

Selanjutnya secara geografis kecamatan yang paling kuat interaksinya dengan Kecamatan Selong sebagai pusat pertumbuhan (diukur dengan nilai indeks gravitasi) adalah Kecamatan Sukamulia, disusul oleh Kecamatan Labuhan Haji, Suralaga, Sakra, dan interaksi terendah adalah Kecamatan Sakra Timur. Kuat lemahnya interaksi tersebut berhubungan erat dengan jauh dekatnya jarak pusat pertumbuhan dengan wilayah pendukungnya. Gambaran ini memang dapat dibuktikan dengan makin maraknya kegiatan pembangunan yang menunjukkan daya dukung kecamatan yang terdekat seperti Sukamulia terhadap Selong. Beberapa dampak langsung antaranya kelancaran dan varian transportasi, pembangunan perumahan, pangkalan BBM (SPBU), gudang aset beberapa kantor/dinas yang ada di Selong, intensitas mobilitas sumber daya manusia, dan lainnya.

Demikian juga dari aspek pengaruh kemajuan pembangunan Selong terhadap daerah sekitarnya menunjukkan prospek yang baik. Secara umum Kecamatan Selong telah memberikan efek positif (spread effect) terhadap kecamatan sekitarnya (daerah pendukung). Hal ini diukur dari Indeks Williamson, yang nilainya rata-rata di bawah 0,5 (mendekati 0). Kecamatan yang memiliki nilai Indeks Williamson yang cukup baik adalah Kecamatan Sukamulia dengan nilai sebesar 0,25 sedangkan Kecamatan Sakra termasuk paling lemah dengan nilai indeks 0,31 . Dengan hasil tersebut Kecamatan Selong telah mampu memberikan spread effect yang baik terhadap daerah pendukung (daerah sekitarnya), karena memang pembangunan ekonomi di kecamatan-kecamatan tersebut cukup merata dan dirasakan manfaatnya.

Dari analisis di atas diketahui bahwa Kecamatan Sukamulia memiliki indeks gravitasi maupun Indeks Williamson rata-rata lebih baik dari kecamatan pendukung lainnya. Dengan posisi strategis tersebut perkembangan ekonomi dan sosial masyarakat Sukamulia menjadi lebih baik dibanding kecamatan lainnya. Oleh karena itu tidak heran kalau Kecamatan Sukamulia relatif lebih banyak memiliki keuntungan dari kemajuan yang dicapai Kota Selong.

\section{Saran}

Sebagai ibu kota kabupaten, Selong tentu harus terus berbenah dan meningkatkan pembangunannya dalam semua aspek. Dengan demikian wilayah-wilayah pendukung sekitarnya akan terpacu dan terimbas dengan kondisi tersebut. Di samping itu, Selong harus tetap menjaga dan mempertahankan eksistensinya sebagai Pusat Kegiatan Wilayah. Untuk itu menjadi tugas pemerintah daerah agar terus meningkatkan fasilitas-fasilitas pendukungnya, terutama di bidang kesehatan dan bidang lainnya untuk menjadikan Selong semakin kuat posisinya sebagai Pusat Kegiatan Wilayah dan kota yang makin maju.

$$
\text { Demikian juga kegiatan-kegiatan }
$$

dalam sektor perekonomian dan perdagangan, sinergitas transportasi antara pusat pertumbuhan (Selong) dengan daerah pendukungnya tetap dipertahankan dan makin ditingkatkan, sehingga roda perekonomian daerah lancar dan berkembang dangan baik. Akses antara pusat pertumbuhan dengan daerah pendukung 
makin diperluas dan diperlancar sehingga efek positif (spread effect) pusat pertumbuhan terhadap wilayah pendukung akan makin besar dan mampu mendorong sektor-sektor ekonomi lain yang belum berkembang selama ini untuk tumbuh. Demikian juga perlu membentuk pusat pertumbuhan baru agar dapat menjangkau kecamatan lain di luar wilayah pendukung untuk berkembang secara merata di wilayah Lombok Timur. Dengan demikian beban pembangunan Selong sebagai ibu kota kabupaten bisa terbagi kepada daerah sekitarnya.

perusahaan.

\section{DAFTAR PUSTAKA}

Adisasmita, Rahardjo. (2005). Dasar-Dasar Ekonomi Wilayah, Yogyakarta: Graha Ilmu.

Adisasmita, Rahardjo. (2008). Pengembangan Wilayah Konsep Dan Teori, Yogyakarta: Graha Ilmu.

Arsyad, Lincolin. (2000). Pengantar Perencanaan dan Pembangunan Ekonomi Daerah, Yogyakarta: BPFE-UGM.

Amaliah, Sri Laily. (2015). Pengaruh Belanja Daerah Terhadap Kemiskinan dan Indeks Pembangunan Manusia di Propinsi Nusa Tenggara Barat 2007-2012. Tesis. Magister IImu Ekonomi Universitas Mataram.

Badan Pusat Statistik, (2016). Statistik Daerah Kabupaten Lombok Timur Tahun 2016. Diperoleh Bulan September 2016, dari https://lomboktimurkab.bps.go.id/.

Badan Pusat Statistik, (2016). Statistik Daerah Provinsi Nusa Tenggara Barat 2016, Diperoleh Bulan Februari 2017, dari http://ntb.bps.go.id/index.php/publikasi/ index?Publikasi.

Daryanto dan Hafizrianda (2010). Model-model Kuantitatif untuk Perencanaan Pembangunan Ekonomi Daerah, Bogor: IPB Press.

Gulo, Yarman. (2015). Identifikasi Pusat-Pusat Pertumbuhan Dan Wilayah Pendukungnya Dalam pengembangan Wilayah Kabupaten Nias. Jurnal Widyariset, 18(1), 65-77.

Ivon, KN. dkk. (2016). Pengaruh Investasi, Pendidikan, Pertumbuhan Penduduk, dan Ekspor Terhadap Pertumbuhan Ekonomi 24 Negara Asia Periode 2005-2013. Jurnal Ekonomi dan Bisnis FEB Universitas Surabaya, 20 (2), 85-94.

Kuncoro, Mudrajad. (2003). Ekonomi Pembangunan, Teori, Masalah dan Kebijakan, Yogyakarta: UPP YKPN.

Kuncoro, Mudrajad. (2012). Perencanaan Daerah : Bagaimana Membangun Ekonomi Lokal, Kota, dan Kawasan, Jakarta: Salemba Empat.

Pemerintah Provinsi Nusa Tenggara Barat. (2010). Peraturan Daerah NTB No. 3 Tahun 2010 tentang Rencana Tata Ruang Wilayah Provinsi (RTRWP) Tahun 2009-2029, diperoleh Bulan Maret 2017, dari http://jdih.ntbprov.go.id/ ?q=content/perda-no-3-tahun-2010. 
50| Hailuddin, Lufuk Fadliyanti, Bq Saripta Wijimulawiani/Pusat Pertumbuhan Ekonomi....

Permatacita, Fitriah. (2012). Analisis Sumber-sumber Pertumbuhan Ekonomi dan Ketimpangan Wilayah di Propinsi Nusa Tenggara Barat. Tesis. Magister Ilmu Ekonomi Universitas Mataram.

Purnamaningsih, Nining. (2009). Analisis Integrasi Wilayah Secara Ekonomi Dan Spacial Di Kediri, Jurnal Fakultas Ekonomi Universitas Kediri, 5(2), 84-98.

Suprihatin, W. dan Hailuddin. (2016). Potensi Pengembangan Sade Sebagai Desa Wisata Lombok. Jurnal Ekonomi dan Bisnis FEB Universitas Surabaya, 20 (2), 71-84.

Sjafrizal. (2012). Ekonomi Wilayah Dan Perkotaan, Jakarta: Grafindo.

Sugiyono. (2012). Metode Penelitian Pendidikan (Pendekatan Kuantitatif, Kualitatif, dan R\&D), Bandung: Alfabeta.

Tarigan. (2005). Ekonomi Regional Teori dan Aplikasi, Jakarta: PT. Bumi Aksara.

Thandi A. Nzama. (2010). Challenges of Suistainable Rural Tourism Development in Kwazulu-Natal. Journal Humaniora \& Social, 2(1), 44-53. 